Domagoj Sajter*

UDK 336.762(497.5)

JEL Classification G11, G23, P27, P33

Preliminary statement

\title{
CAN CROATIAN FUND MANAGERS CREATE ALPHA RETURNS? PERFORMANCE OF SOME MUTUAL FUNDS IN CROATIA
}

The research object of this paper is to scrutinize the risk-adjusted returns of the five largest Croatian open-end equity mutual funds (ZB Aktiv, PBZ Equity, Raiffeisen Central Europe, Erste Adriatic Equity, and ZB Trend), and to compare each of them individually with a selection of the risk-adjusted returns of 10 relevant stock market indices (Crobex, S\&P500, Rts50, Belex15, Atx20, Cetop20, Nikkei225, Bux13, Ftse100, and SSE Composite). Jensen alphas were calculated in order to obtain insight into the performance of the funds, with the intention of evaluating the successfullness of the actively managed equity mutual funds in Croatia.

Three time periods were observed, and each of the funds is examined in its own time frame. The first period dates from the funds' establishment until July 2010; the second is from the funds' establishment until January 2008. Specific interest was taken into the period of global financial crisis (in Croatia from the beginning of 2008 onwards), and into the performance of the funds during this downturn. Therefore, the third period spans from February 2008 until July 2010. Altogether, 150 individual OLS specifications were taken into account.

Null hypothesis was confirmed, since Jensen alphas indicate underperformance of the funds when compared to market returns. Even though positive (albeit relatively small) alphas were shown in the period of extreme

"D. Sajter, Ph.D., Assistant Professor, Faculty of Economics in Osijek (e-mail: sajter@efos.hr) The paper was received on April 18th 2011. 
(exponential) growth of the Croatian mutual fund industry (2000 - 2008), these returns have proven themselves to be unsustainable in the long term.

Keywords: Active management, mutual fund performance, Jensen alpha, Treynor, Sharpe, Croatia

\section{Introduction}

There are numerous papers aiming to clarify the matter of superiority of either passive or active fund management, and their results are sometimes conflicting. Nevertheless, many of them ${ }^{1}$ find that the latter often cannot exceed returns created by the overall market. The very notion that the majority of financial professionals, employing all of their expertise, knowledge, intuition, skills, intelligence and wit, cannot generate returns which are significantly higher than the returns obtained by those who aren't blessed with the aforementioned virtues, and who are simply following the market (without any deeper insights into it whatsoever), is for some exceptionally hard to acknowledge.

Even though results throughout many studies exhibit evidence to the contra$\mathrm{ry}^{2}$, most of the Croatian investors believe that their capital will be better off in the hands of the financial professionals, as actively managed funds represent $99,00 \%$ of the total mutual fund assets in Croatia ${ }^{3}$. However, until recently Croatian retail investors were not given opportunities to invest into financial instruments which bore (strictly) market returns. Certificates and ETFs are still largely unknown in Croatia, and passively managed mutual funds have started operating only in February 2010. Therefore, prior to February 2010 actively managed mutual funds were practically the only investment option for the Croatian retail investors who aspired towards market returns, but did not want to get personally involved into market research and trading on a regular (daily, or less frequent) basis.

Given these circumstances, the aim of this study is to scrutinize the returns generated by the largest Croatian open-end actively managed equity mutual funds, and to compare them with the array of stock market indices (benchmarks), thus revealing management competence in delivering extra performance.

The time period will span the whole life of the examined mutual funds, from their establishment until the time when this paper was being prepared (October

1 For instance, Sharpe (1966), Jensen (1967), Malkiel (1995), Gruber (1996), Carhart (1997), Daniel et al. (1997).

2 See footnote 1.

3 October 2010, source: Croatian Financial Service Supervisory Agency (HANFA) 
2010). Furthermore, the observed time period will be divided into different subsets, trying to examine the impact of the worldwide financial crisis in the late 2000s on this particular segment of the Croatian financial industry.

\section{Previous studies}

It is certainly beyond the scope of this paper to mention all (or most) of the numerous studies in this field. Bearing this in mind, the focus will be on the work in this field which has been done in Croatia, only mentioning a few relevant international studies.

Sharpe (1966) introduced simple and "meaningful measure that considers both average return and risk" ity ratio, which relates excess return over the risk-free rate to the systematic risk (beta). Jensen (1967) launched a measure to determine the nonstandard return of a security (or portfolio) over the theoretical expected return. Examining 115 mutual funds in the period of 1945 - 1964 he found that not a single one of them was able to do significantly better than it was expected, and concluded that there is a "pressing need on the part of the funds themselves to evaluate much more closely both the costs and the benefits of their research and trading activities in order to provide investors with maximum possible returns for the level of risk undertaken." ${ }^{5}$

Following previously mentioned articles a strong inflow of research interest yielded a number of significant papers, which primarily analyzed the U.S. market. After the first-generation of mutual fund studies (published between 1962 and 1970) Ippolito (1989) examined 143 mutual funds over the period 1965-1984, and found that mutual funds outperformed index funds on a risk-adjusted basis. Nonetheless, he adds that "the industry alpha (...) is not sufficiently large to overcome the load charges that characterize the majority of funds" es and charges affiliated with mutual funds are offset by superior results" 7 . Bogle (1991) shows that S\&P500 outperformed the majority of U.S. equity mutual funds in the period from 1970 to 1989 . While examining the performance of diversified U.S. domestic equity funds Harlow and Brown (2006) state that "over the period from 1979 to 2003 the typical mutual fund produced returns that failed to meet expectations" $"$.

\footnotetext{
4 Sharpe (1966: 137)

5 Jensen (1967: 415)

6 Ippolito (1989: 20)

7 Ippolito (1989: 21)

8 Harlow and Brown (2006: 21)
} 
Active management performance in Europe was less scrutinized. Pushner and Rainish (2001) evaluated returns of 57 U.S. based open-end mutual funds that invest primarily in European securities. They found that majority of them do not exceed the returns of the MSCI European Index, and that they do not show positive risk-adjusted returns. On the contrary, Otten and Bams (2002) examined 506 mutual funds from 5 European countries; their results show that "most European mutual funds (...) deliver positive risk-adjusted performance" , and that the majority of European funds seem to be able to add value for the investors. Rodriguez (2008) had similar results, concluding that fund managers surpassed the MSCI European index during the sample period (January 1999 - September 2004) as evidenced by a positive and significant average value of Jensen alpha.

As for papers from Croatia, most of the research done in the field of mutual fund industry has not dealt with the active management performance issues. Morić Milovanović and Galetić (2005), similar to Jurić (2005), presented a general overview of the Croatian mutual fund industry at the time. Galetić et al. (2007) tried to explain the relationship between the main Zagreb Stock Exchange index (Crobex) and the returns of the five largest Croatian equity mutual funds. Their results display a positive relation between Crobex and funds' performance ${ }^{10}$. Novak and Sajter (2007) calculated Value-at-Risk for a selection of equity and balanced Croatian mutual funds, thereby introducing and popularizing risk measures in the field. Valdevit et al. (2008) analyzed concentration in the industry using Herfindahl-Hirschman, Theil enthropy, and similar indices. Čondić-Jurkić and Dadic (2008) showed that 4 out of the 10 observed Croatian mutual funds were Johansen cointegrated with the Crobex index, implying that these funds spontaneously followed a passive investment strategy ${ }^{11}$.

As stated before, evaluation of fund performance in comparison with relevant benchmark indices (market returns), with the aim of concluding as to whether active management produces superior yields, was not previously done.

Given all the past studies, and sometimes conflicting results, it is certainly interesting to investigate how Croatian mutual fund managers route and employ their clients' money, and the bottom-line outcome of their portfolio-choices.

\footnotetext{
9 Otten and Bams (2002: 99)

10 This is quite straightforward, since these funds invested primarily in the Crobex constituents.

${ }^{11}$ However, due to the small size and narrowness of the Croatian financial market, and (as a consequence) a limited choice of investable domestic stocks, overlapping of Crobex constituents and components in the funds' portfolio was (and still is) inevitable.
} 


\section{An overview of the Croatian mutual fund industry}

The Croatian mutual fund industry grew extremely rapidly during the years 2000 to 2008. The first open-end mutual funds began operating in 1999, and in the successive period their number grew from 14 (in 2001) to 103 (peak in May 2009), as presented in Figure 1.

The total assets of all open-end mutual funds in Croatia increased from $€ 3.3$ million in 1999 to $€ 4.0$ billion (highest point, December 2007). Growth was nothing less than exponential - that is, until the burst of the bubble, which happened in 2008 (Figure 2).

As for the ranking of the funds according to their asset size, the five year period (from 12/2006 to 08/2010) shows that the standings remained relatively stable, with the exception of a newcomer into the top 6 - the ZB Euroaktiv fund (in the year 2010). The largest Croatian open-end equity mutual fund in the period is ZB Aktiv, PBZ Equity follows, while $3^{\text {rd }}$ and $4^{\text {th }}$ place are interchanged by Raiffeisen Central Europe and Erste Adriatic Equity funds (Figure 3).

It is obvious (even without deeper analysis) that the concentration of openend equity mutual funds in Croatia was and still is relatively high, with 3 of the

Figure 1.

NUMBER AND TYPE OF ALL OPEN-END MUTUAL FUNDS IN CROATIA

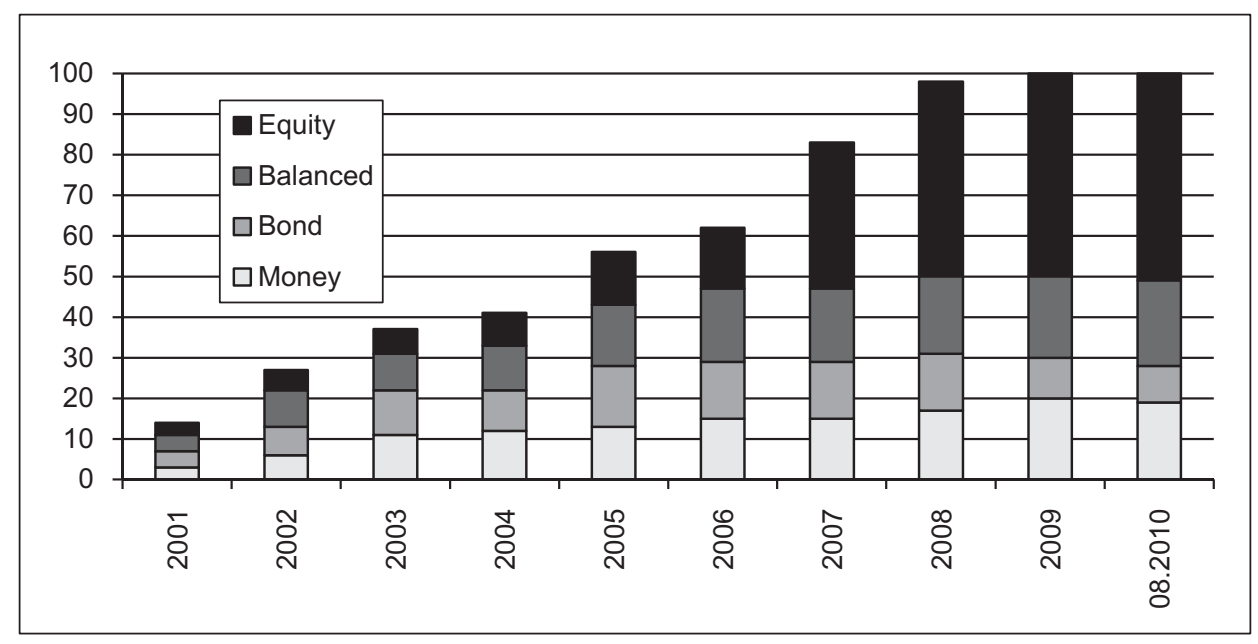

Source: Croatian Financial Service Supervisory Agency (HANFA) 
top 7 funds managed by ZB Invest ${ }^{12}$, and 2 of the top 6 managed by PBZ Invest ${ }^{13}$ (in August 2010, Table 1).

Figure 2 .

TOTAL ASSETS OF ALL OPEN-END MUTUAL FUNDS IN CROATIA

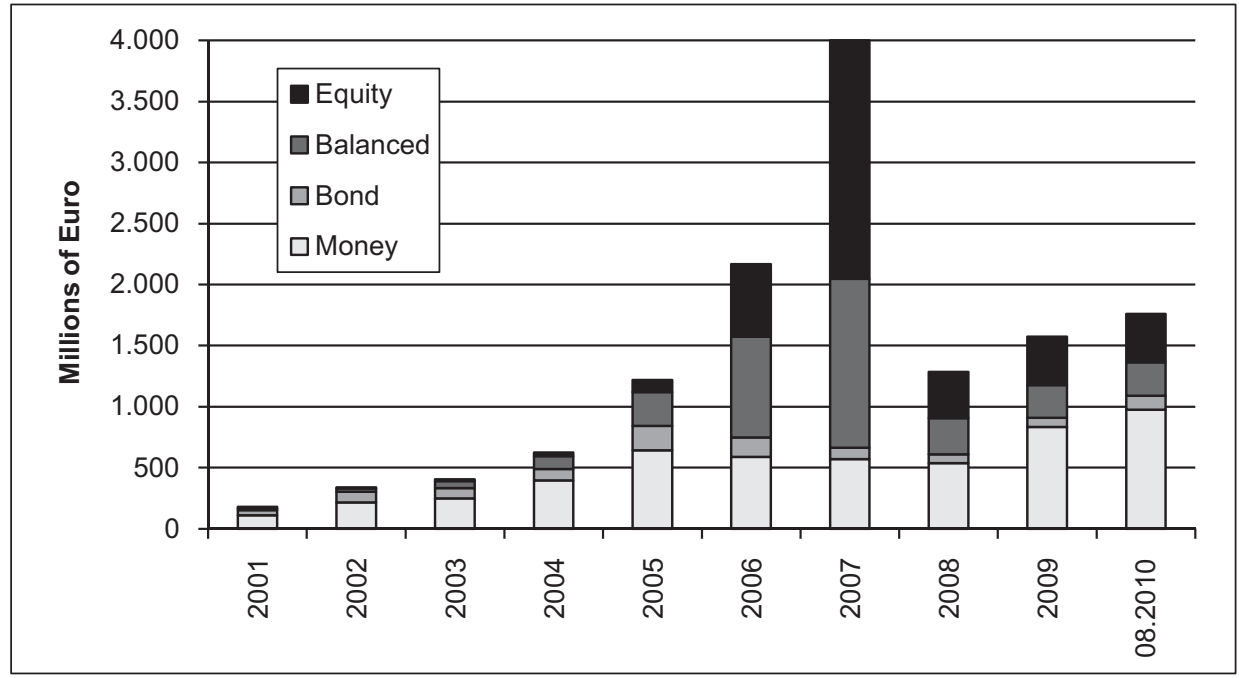

Source: Croatian Financial Service Supervisory Agency (HANFA)

12 Zagrebačka Bank Invest, Limited Liability Company registered for mutual fund management.

13 Privredna Bank Zagreb Invest, Limited Liability Company registered for mutual fund management. 
Figure 3.

ASSET SIZE OF THE LARGEST OPEN-END EQUITY MUTUAL FUNDS IN CROATIA IN THE PERIOD 12/2006 TO 08/2010

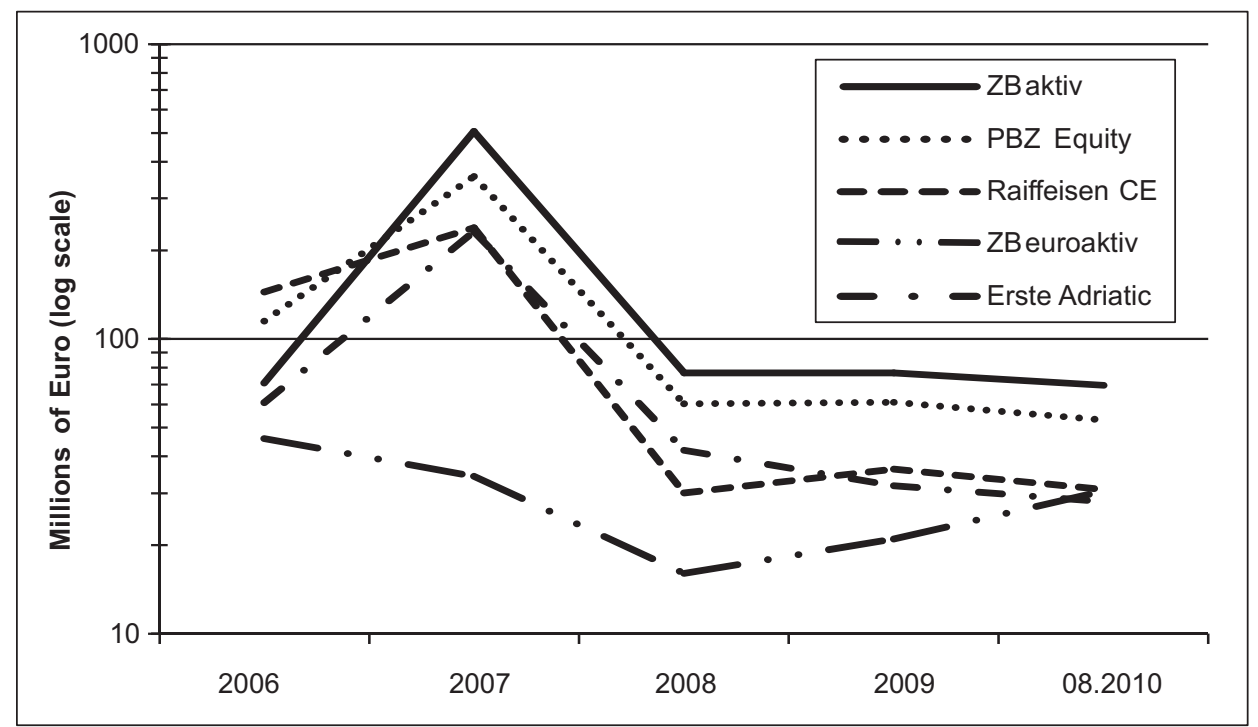

Source: Croatian Financial Service Supervisory Agency (HANFA)

Table 1.

RANKINGS AND ESTABLISHMENT DATES OF THE LARGEST OPEN-END EQUITY MUTUAL FUNDS IN CROATIA ACCORDING TO THEIR ASSET SIZE (AUGUST 2010)

\begin{tabular}{|c|l|c|c|}
\hline Rank & \multicolumn{1}{|c|}{ Fund } & $\begin{array}{c}\text { Net assets, August } \\
2010(\text { mil. } €)\end{array}$ & $\begin{array}{c}\text { Established } \\
(\text { dd.mm.yyyy. })\end{array}$ \\
\hline 1 & ZB Aktiv & 69.71 & 26.06 .2006$. \\
\hline 2 & PBZ Equity & 53.08 & 05.09 .2005$. \\
\hline 3 & Raiffeisen Central Europe & 30.87 & 22.04 .2005$. \\
\hline 4 & ZB Euroaktiv* & 30.53 & 05.05 .2004$. \\
\hline 5 & Erste Adriatic Equity & 28.08 & 11.10 .2005$. \\
\hline 6 & PBZ I-Stock fond* & 27.78 & 17.07 .2007$. \\
\hline 7 & ZB Trend & 22.44 & 28.10 .2002$. \\
\hline
\end{tabular}


Unfortunately, passively managed open-end mutual funds in Croatia did not exist prior to February 2010. Consequently, most of the Croatian retail investors did not have an opportunity to invest into the investment vehicles which bore market returns, and at the same time had lower expense ratios. Nonetheless, the sheer inexistence of such investment vehicles does not hinder researchers from evaluating the active management performance of the present mutual funds, and from comparing them to market returns.

\section{Data and methodology}

All of the data used in this study is obtainable by free-to-access public information resources. The Croatian funds' data was collected from the Kapital-Plus internet porta ${ }^{14}$, Crobex index data was taken from the Zagreb Stock Exchange website $^{15}$, and the remaining indices data was obtained either from Yahoo Finance service $^{16}$, or from the websites of the respective exchanges.

Given the asset size and rankings of the Croatian equity funds (Figure 3 and Table 1), this paper focuses on the largest Croatian mutual equity funds. Among these, PBZ I-Stock fund is excluded from the analysis due to its late entry into the market ${ }^{17}$, as well as ZB Euroaktiv fund, since its asset size in the period prior to 2009 indicated that it was a relatively inconsiderable fund which has only recently gained some momentum. Following this, the observed funds in this study are the following five:

a) ZB Aktiv, b) PBZ Equity, c) Raiffeisen Central Europe, d) Erste Adriatic Equity, and e) ZB Trend.

As for benchmarks returns, each of the funds was compared with a selection of five relevant stock market indices, according to the geographical exposure of funds' assets ${ }^{18}$. With the exception of ZB Trend, Crobex certainly has the highest significance among the benchmarks, since the largest Croatian funds invest

\footnotetext{
14 http://www.kapital-plus.net/ (Accessed in August 2010)

$15 \mathrm{http} / / / \mathrm{www} . z s e . h r /$ (Accessed in August 2010)

$16 \mathrm{http}: / /$ finance.yahoo.com/ ; with the exception of Wig20 index data, which was taken from http://www.stooq.pl (both accessed in August 2010)

17 It was founded in July 2007, and shortly after its establishment it was struck with the effects of global financial crisis. Consequently, most of its existence is in the period of abnormal market behaviour.

18 It should be noted that other regional (Central- and Eastern-European) indices were also examined in the first version of this paper, and the results and conclusions were not much different than those presented in this version.
} 
mainly in the domestic stocks. The funds' geographical exposure and the selection of indices is presented in Table 2. The significance of each index as a benchmark is approximately proportional to the share of the funds' assets invested in the respective index constituents.

Table 2.

\section{GEOGRAPHICAL EXPOSURE OF FUNDS' ASSETS AND SELECTION OF BENCHMARK INDICES ${ }^{19}$}

\begin{tabular}{|c|c|c|c|c|c|c|c|c|c|}
\hline \begin{tabular}{|l|} 
ZB \\
Aktiv \\
\end{tabular} & $\%$ & PBZ Equity & $\%$ & \begin{tabular}{|l|} 
ZB \\
Trend \\
\end{tabular} & $\%$ & \begin{tabular}{|l|} 
Raiffeisen \\
CE \\
\end{tabular} & $\%$ & \begin{tabular}{|l|} 
Erste \\
$\mathrm{AE}$ \\
\end{tabular} & $\%$ \\
\hline Croatia & 32,04 & Croatia & 48,99 & USA & 36,02 & Croatia & 48,18 & Croatia & 60,78 \\
\hline Russia & 23,20 & Ex-Yugoslavia & 16,66 & Croatia & 23,64 & Slovenia & 11,20 & Serbia & 18,60 \\
\hline Serbia & 17,84 & New Europe & 8,98 & Japan & 8,88 & Austria & 10,00 & Slovenia & 8,89 \\
\hline USA & 11,83 & Russia & 5,50 & \begin{tabular}{|l} 
G. \\
Britain
\end{tabular} & 7,00 & Serbia & 7,79 & Russia & 7,15 \\
\hline China & 3,28 & & & Canada & 6,62 & $\begin{array}{l}\text { Bosnia } \\
\text { and H. }\end{array}$ & 6,41 & & \\
\hline & & & & China & 3,29 & & & & \\
\hline$\Sigma$ & 88,19 & $\Sigma$ & 83,01 & $\Sigma$ & 85,45 & $\Sigma$ & 83,58 & $\Sigma$ & 95,42 \\
\hline \multicolumn{10}{|c|}{ ck market indices chosen as benchmarks for the respective funds: } \\
\hline $\begin{array}{l}\text { Crobex } \\
\text { Rts50 } \\
\text { Belex15 } \\
\text { S\&P500 } \\
\text { SSE Con }\end{array}$ & nposite & \multicolumn{2}{|l|}{$\begin{array}{l}\text { Crobex } \\
\text { Belex15 } \\
\text { Cetop20 } \\
\text { Bux13 } \\
\text { Rts50 }\end{array}$} & \multicolumn{2}{|c|}{$\begin{array}{l}\text { S\&P500 } \\
\text { Crobex } \\
\text { Nikkei225 } \\
\text { Ftse100 } \\
\text { SSE Composite }\end{array}$} & \multicolumn{2}{|l|}{$\begin{array}{l}\text { Crobex } \\
\text { Atx20 } \\
\text { Cetop20 } \\
\text { Belex15 } \\
\text { Bux13 }\end{array}$} & \multicolumn{2}{|l|}{$\begin{array}{l}\text { Crobex } \\
\text { Belex15 } \\
\text { Cetop20 } \\
\text { Atx20 } \\
\text { Rts50 }\end{array}$} \\
\hline
\end{tabular}

Even though a smaller number of benchmarks would be sufficient in capturing the majority of geographical exposure for some of the funds (for instance,

19 Due to high correlation of Canadian and US markets S\&P500 was chosen to represent both US and Canadian markets; SSE Composite was selected to represent Chinese stock market rather than Hang Seng, because of the orientation of the latter to Hong Kong; Cetop20 (as an index which consists of 20 most liquid Central and Eastern European companies, quoted on Budapest Exchange) and Atx20 (as a neighbouring and correlated market) were selected to represent Slovenian market, which (the same as Bosnian and Herzegovinian market) was considered too narrow and therefore not enough trustworthy to be considered for this kind of research. 
Crobex and Belex 15 cover 79,4\% of Erste Adriatic Equity's geographical exposure), five indices were chosen for each fund in order to have a balanced view across funds. In addition to this reasoning, increasing the number of benchmarks can only strengthen results, not weaken them.

After summing up all the data, corrections were done for non-mutual national holidays (i.e. non-working days). Afterwards, monthly returns were computed, and this data was tested for stationarity; a standard ADF test showed no present unit roots, neither in the funds nor in the indices ${ }^{20}$.

Each of the observed funds is examined in its own specific time frame. The general period of observation spans from each of the funds' establishment until August $2010^{21}$. This hinders direct comparison among funds, but the aim of this paper is not to compare funds among themselves, but to weigh each of the funds' return against benchmark returns. In addition, in order to examine active management performance in the circumstances of the global financial crisis of the late 2000 s, the time frame will be split into pre-crisis and post-crisis period (with the turning point in Croatia being at the end of January 2008). During this severe downturn actively managed funds are expected to lose less then market indices (similar to how they are expected to gain more in times of expansion). Thus, there are three observed periods:

A) from the funds' establishment to August 2010,

B) from the funds' establishment until the end of January 2008,

C) from February 2008 to August 2010.

Hence, in terms of dates it is clear that $\mathrm{B}+\mathrm{C}=\mathrm{A}$. Furthermore, period $\mathrm{C}$ allows us to compare funds and markets among themselves, since all of the funds operated in this period.

Both absolute and risk-adjusted performances of the funds are examined, using following standard measures:

$$
\begin{aligned}
& S=\frac{R_{i}-R_{f}}{\sigma_{i}}, \\
& T=\frac{R_{i}-R_{f}}{\beta_{i}}, \\
& J_{\alpha}=R_{i}-\left[R_{f}+\beta_{i}\left(R_{m}-R_{f}\right)\right]
\end{aligned}
$$

20 Detailed data is available from author upon request.

21 Longest period is October 2002 - July 2010 for ZB Trend fund, and shortest is June 2006 - July 2010 for ZB Aktiv fund. 
where $\mathrm{T}=$ Treynor ratio, $\mathrm{S}=$ Sharpe ratio, $\mathrm{J}_{\alpha}=$ Jensen alpha, $\mathrm{R}_{\mathrm{i}}=$ portfolio's return, $\mathrm{R}_{\mathrm{f}}=$ risk free rate, $\beta_{\mathrm{i}}=$ portfolio's beta, $\sigma_{\mathrm{i}}=$ portfolio's volatility, and $\mathrm{R}_{\mathrm{m}}=$ market return ${ }^{22}$.

In these terms, main hypothesis of this paper states as follows:

$$
\mathrm{H}_{0}: \mathrm{J}_{\alpha \mathrm{i}} \leq 0
$$

presuming that Jensen alpha for each of the funds examined indicates underperformance of a particular fund when compared to chosen benchmarks.

Sharpe ratio exhibits whether funds' returns are a result of smart investment decisions or of excess risk. This measurement is useful because although one fund can accomplish higher returns than competition, it is only a good investment if those higher returns do not come with too much additional risk. Treynor ratio is similar ratio to the Sharpe ratio, except that the beta of the stock market index is taken as a measure of risk, instead of the volatility of fund returns.

Although useful as ranking mechanisms, neither Sharpe nor the Traynor ratios quantify the value added of active portfolio management. On the other hand, Jensen alpha is one of the ways to help determine if a fund is earning the proper return for its level of risk, but it also measures the extra performance of a given fund. If the value is positive, then the fund is earning excess returns over the market index; a positive value for Jensen alpha means a fund manager has "beat the market" with his stock picking skills.

The average monthly interest rate on the Croatian Ministry of Finance's treasury bills (maturity: 364 days) was taken as the risk-free interest rate ${ }^{23}$. Taken in this manner, the risk-free interest rate is relatively high; it is so because it reflects the perceived overall riskiness of the Croatian financial market, with all of its specific transitional traits. Having this in mind, in order to observe the effect of the risk-free rate Jensen alphas will be calculated including, as well as excluding risk-free rates.

22 Market return is here examined through ten relevant stock market indices.

23 Risk-free interest rate is calculated according to the Decision of the Government of the Republic of Croatia (Official Gazette, No. 114/2008), which transfers and enacts the Communication of the European Commission on the revision of the method for setting the reference and discount rates (52008XC0119(01), OJ C 14/2008. Data upon Treasury bills' returns is obtained from Croatian Ministry of Finance website: http://www.mfin.hr/ (accessed in October 2010). 


\section{Results}

As stated before, each of the observed five funds will be compared with five benchmark returns. Regressions are modelled with the monthly fund returns (after subtracting risk free rate) being the dependent variable, and market returns (also after subtracting risk free rate) being the independent variable. Estimated coefficients are taken to exhibit Traynor ratio and Jensen alpha. Since the risk-free rate is relatively high, Jensen alphas were also computed without the effect of the Croatian Treasury bills' interest rate ${ }^{24}$.

It should also be noticed that the management fees ${ }^{25}$ are taken into consideration, since funds publish their returns on a net basis, and fees are already subtracted.

First presented (Table 3) are performances of the funds in the period A: from the funds' establishment until August 2010. Sharpe and Traynor ratios portray a situation in which funds, as well as market returns, underperform Croatian treasury bills on average and have negative average excess returns. However, "the rule" of the larger ratio, the better (less negative), still applies ${ }^{26}$. Sharpe ratios for all of the funds are lower than Sharpe ratios of benchmarks ${ }^{27}$. Additionally, Jensen alphas are negative for all of the funds across all the benchmarks, with the exception of the ZB Trend fund, but only when risk-free rate is not taken into consideration.

Table 4 exhibits funds' performance in the period from their establishment until the end of January 2008, that is before the beginning of the global financial crisis. This is the period of high growth and strong expansion of the Croatian financial market. When observing risk-reward relationship, ZB Aktiv, PBZ Equity, and Erste AE have higher Sharpe ratios than their benchmarks; Raiffeisen CE has not beaten Crobex (its by far main area of exposure), while Sharpe ratio for ZB Trend is lower than all of its benchmarks.

Jensen alphas are not completely in line with Sharpe ratios in the period B; this measure shows that (with the exception of ZB Trend, which has not been able

${ }^{24}$ Taken in this manner Jensen alphas are computed solving: $J \alpha=R i-\beta R m$ (exhibited in the last column in Tables $3-5$ )

25 According to the Article 65 of the Croatian Investment funds Act (Official Gazette, No. $150 / 2005)$, total management fees can reach a maximum of $3.5 \%$.

26 At first it may seem as counterintuitive, but interpretation of negative Sharpe ratios is the same as interpretation of the positive Sharpe ratios, as ,the fund with the maximum Sharpe ratio is that fund with the highest probability of outperforming the risk free rate, not necessarily the fund with the largest excess return per unit of risk" (McLeod \& van Vuuren, 2004, p.19).

27 The only exception is ZB Aktiv, which has higher Sharpe ratio than S\&P500 in the observed period. However, this is rather insignificant because only 11,83\% of ZB Aktiv's assets are invested in the USA. 
to surpass its benchmarks) all of the funds have created returns higher than market returns. However, these positive alphas are relatively low (mostly between 1\% and $2 \%$ ) and cannot cover the management fees of the funds, which range from $2,15 \%$ to $2,30 \%$ at the examined funds ${ }^{28}$. In other words, when fees are taken into account the largest funds in Croatia in the period of strong growth did not create excess return for their investors.

Finally, Table 5 presents funds' and market performance during the period of crisis and afterwards, when markets experienced collapse. In this period the objective of active management is to suffer less, or to experience lower negative returns. This is an assignment that wasn't accomplished, as for most of the observed funds' risk-adjusted returns were lower than those of the stock market indices. Jensen alphas (with or without th effect of the risk-free rate) exhibit that funds have lost more value than market indices.

The exception here is ZB Trend, which in this period outperformed all of the funds, as well as some its benchmarks (Table 5). On the other hand, the "positive" performance of ZB Trend is relative; value added by ZB Trend is lower than $0,50 \%$, and does not even cover the bank deposit fee charged by the management.

All of the results clearly show that, in general, Croatian fund managers cannot significantly outperform the Croatian stock market index and selected benchmark indices, neither in the period of high growth, neither in times of crisis.

28 Actually, fund management fee at all observed funds is $2,00 \%$, but beside this investors also have to bear the „bank deposit fee“, which ranges from $0,15 \%$ to $0,30 \%$. Therefore, the total varies from $2,15 \%$ to $2,30 \%$. 
Table 3.

\section{PERFORMANCES OF THE LARGEST CROATIAN ACTIVELY MANAGED EQUITY MUTUAL FUNDS IN THE PERIOD FROM THEIR ESTABLISHMENT UNTIL AUGUST 201}

\begin{tabular}{|c|c|c|c|c|c|c|c|c|}
\hline Fund/Index & $\begin{array}{c}\text { Observation } \\
\text { period }\end{array}$ & $\begin{array}{l}\text { Total } \\
\text { return }\end{array}$ & $\begin{array}{c}\text { Average } \\
\text { return } \\
\text { (monthly) }\end{array}$ & $\begin{array}{l}\text { Volatility } \\
\text { (monthly) }\end{array}$ & $\begin{array}{l}\text { Sharpe } \\
\text { Ratio }\end{array}$ & $\begin{array}{c}\text { Treynor } \\
\text { Ratio }\end{array}$ & $\begin{array}{c}\text { Jensen } \\
\alpha\end{array}$ & $\begin{array}{l}\text { Jensen } \alpha, \\
\text { w/out Rf }\end{array}$ \\
\hline ZB Aktiv & \multirow{6}{*}{$\begin{array}{c}07 / 2006- \\
08 / 2010\end{array}$} & $-16,11 \%$ & $-0,14 \%$ & $6,64 \%$ & $-8,31 \%$ & \multicolumn{3}{|c|}{${ }_{2}$} \\
\hline Crobex & & $-31,58 \%$ & $-0,22 \%$ & $10,52 \%$ & $-6,01 \%$ & $-1,13 \%$ & $-0,20 \%$ & $-0,02 \%$ \\
\hline Rts50 & & $-1,00 \%$ & $0,75 \%$ & $12,24 \%$ & $2,75 \%$ & $0,90 \%$ & $-0,68 \%$ & $-0,42 \%$ \\
\hline Belex15 & & $-38,65 \%$ & $-0,07 \%$ & $13,61 \%$ & $-3,57 \%$ & $-1,14 \%$ & $-0,35 \%$ & $-0,11 \%$ \\
\hline S\&P500 & & $-13,27 \%$ & $-0,14 \%$ & $5,41 \%$ & $-10,27 \%$ & $-0,67 \%$ & $-0,09 \%$ & $-0,02 \%$ \\
\hline SSE Comp. & & $148,25 \%$ & $2,63 \%$ & $12,29 \%$ & $18,03 \%$ & $9,55 \%$ & $-1,07 \%$ & $-0,75 \%$ \\
\hline PBZ Equity & \multirow{6}{*}{$\begin{array}{c}10 / 2005- \\
08 / 2010\end{array}$} & $-27,89 \%$ & $-0,29 \%$ & $7,27 \%$ & $-9,74 \%$ & \multicolumn{3}{|c|}{ 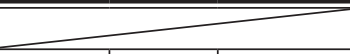 } \\
\hline Crobex & & $-8,99 \%$ & $0,33 \%$ & $9,92 \%$ & $-0,84 \%$ & $-0,12 \%$ & $-0,65 \%$ & $-0,52 \%$ \\
\hline Belex15 & & $-37,91 \%$ & $-0,03 \%$ & $12,68 \%$ & $-3,50 \%$ & $-0,90 \%$ & $-0,51 \%$ & $-0,30 \%$ \\
\hline Bux13 & & $-1,16 \%$ & $0,30 \%$ & $7,96 \%$ & $-1,38 \%$ & $-0,18 \%$ & $-0,64 \%$ & $-0,48 \%$ \\
\hline Cetop20 & & $-8,01 \%$ & $0,27 \%$ & $8,97 \%$ & $-1,62 \%$ & $-0,30 \%$ & $-0,64 \%$ & $-0,42 \%$ \\
\hline Rts50 & & $46,83 \%$ & $1,40 \%$ & $11,93 \%$ & $8,23 \%$ & $2,29 \%$ & $-0,89 \%$ & $-1,13 \%$ \\
\hline Raiffeise & \multirow{6}{*}{$\begin{array}{c}05 / 2005- \\
08 / 2010\end{array}$} & $-39,44 \%$ & $-0,49 \%$ & $7,62 \%$ & $-11,83 \%$ & \multicolumn{3}{|c|}{1} \\
\hline Crobex & & $3,80 \%$ & $0,52 \%$ & $9,57 \%$ & $1,11 \%$ & $0,15 \%$ & $-0,98 \%$ & $-0,86 \%$ \\
\hline Atx20 & & $-3,20 \%$ & $0,29 \%$ & $8,08 \%$ & $-1,52 \%$ & $-0,17 \%$ & $-0,81 \%$ & $-0,70 \%$ \\
\hline Belex15* & & $-37,91 \%$ & $-0,03 \%$ & $12,68 \%$ & $-3,50 \%$ & $-0,84 \%$ & $-0,99 \%$ & $-0,79 \%$ \\
\hline Bux13 & & $38,50 \%$ & $0,84 \%$ & $7,90 \%$ & $5,36 \%$ & $0,62 \%$ & $-1,19 \%$ & $-1,06 \%$ \\
\hline Cetop20 & & $33,57 \%$ & $0,86 \%$ & $8,85 \%$ & $5,08 \%$ & $0,81 \%$ & $-1,15 \%$ & $-0,97 \%$ \\
\hline Erste AE & \multirow{6}{*}{$\begin{array}{c}11 / 2005- \\
08 / 2010\end{array}$} & $-15,34 \%$ & $-0,10 \%$ & $6,19 \%$ & $-8,27 \%$ & \multicolumn{3}{|c|}{1} \\
\hline Crobex & & $-8,35 \%$ & $0,35 \%$ & $10,01 \%$ & $-0,65 \%$ & $-0,11 \%$ & $-0,47 \%$ & $-0,30 \%$ \\
\hline Belex15 & & $-37,91 \%$ & $-0,03 \%$ & $12,68 \%$ & $-3,50 \%$ & $-1,13 \%$ & $-0,34 \%$ & $-0,09 \%$ \\
\hline Cetop20 & & $2,06 \%$ & $0,45 \%$ & $8,94 \%$ & $0,36 \%$ & $0,08 \%$ & $-0,53 \%$ & $-0,28 \%$ \\
\hline Atx20 & & $-24,70 \%$ & $-0,14 \%$ & $8,25 \%$ & $-6,71 \%$ & $-1,04 \%$ & $-0,22 \%$ & $-0,02 \%$ \\
\hline Rts50 & & $57,07 \%$ & $1,53 \%$ & $11,98 \%$ & $9,34 \%$ & $3,41 \%$ & $-0,88 \%$ & $-0,60 \%$ \\
\hline ZB Trend & \multirow{6}{*}{$\begin{array}{c}11 / 2002- \\
08 / 2010\end{array}$} & $26,61 \%$ & $0,29 \%$ & $2,82 \%$ & $-4,27 \%$ & \multicolumn{3}{|c|}{ 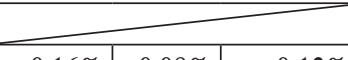 } \\
\hline S\&P500 & & $24,37 \%$ & $0,33 \%$ & $4,38 \%$ & $-1,87 \%$ & $-0,16 \%$ & $-0,08 \%$ & $0,12 \%$ \\
\hline Crobex & & $69,36 \%$ & $0,95 \%$ & $8,68 \%$ & $6,12 \%$ & $3,02 \%$ & $-0,21 \%$ & $0,13 \%$ \\
\hline Nikkei225 & & $10,38 \%$ & $0,28 \%$ & $5,81 \%$ & $-2,32 \%$ & $-0,38 \%$ & $-0,07 \%$ & $0,19 \%$ \\
\hline Ftse100 & & $31,74 \%$ & $0,38 \%$ & $4,18 \%$ & $-0,71 \%$ & $-0,05 \%$ & $-0,10 \%$ & $0,08 \%$ \\
\hline SSE Comp. & & $144,62 \%$ & $1,47 \%$ & $10,03 \%$ & $10,51 \%$ & $16,46 \%$ & $-0,19 \%$ & $0,20 \%$ \\
\hline
\end{tabular}


Table 4.

\section{PERFORMANCES OF THE LARGEST CROATIAN ACTIVELY MANAGED EQUITY MUTUAL FUNDS IN THE PERIOD FROM THEIR ESTABLISHMENT UNTIL THE END OF JANUARY 2008}

\begin{tabular}{|c|c|c|c|c|c|c|c|c|}
\hline Fund/Index & $\begin{array}{l}\text { Observation } \\
\text { period }\end{array}$ & $\begin{array}{l}\text { Total } \\
\text { return }\end{array}$ & $\begin{array}{l}\text { Average } \\
\text { return } \\
\text { (monthly) }\end{array}$ & $\begin{array}{l}\text { Volatility } \\
\text { (monthly) }\end{array}$ & $\begin{array}{l}\text { Sharpe } \\
\text { Ratio }\end{array}$ & $\begin{array}{c}\text { Treynor } \\
\text { Ratio }\end{array}$ & $\begin{array}{c}\text { Jensen } \\
\alpha\end{array}$ & $\begin{array}{l}\text { Jensen } \alpha \text {, } \\
\text { w/out Rf }\end{array}$ \\
\hline ZB Aktiv & \multirow{6}{*}{$\begin{array}{c}07 / 2006- \\
01 / 2008\end{array}$} & $72,57 \%$ & $3,04 \%$ & $5,09 \%$ & $52,63 \%$ & & & \\
\hline Crobex & & $65,73 \%$ & $2,97 \%$ & $7,64 \%$ & $34,17 \%$ & $4,73 \%$ & $1,24 \%$ & $1,40 \%$ \\
\hline Rts50 & & $27,59 \%$ & $1,50 \%$ & $6,58 \%$ & $17,40 \%$ & $3,50 \%$ & $2,30 \%$ & $2,54 \%$ \\
\hline Belex15 & & $110,12 \%$ & $4,53 \%$ & $11,09 \%$ & $37,64 \%$ & $11,92 \%$ & $1,21 \%$ & $1,45 \%$ \\
\hline S\&P500 & & $8,53 \%$ & $0,47 \%$ & $2,84 \%$ & $3,90 \%$ & $0,10 \%$ & $2,55 \%$ & $2,50 \%$ \\
\hline SSE Comp. & & $202,68 \%$ & $6,62 \%$ & $11,62 \%$ & $53,86 \%$ & $27,14 \%$ & $1,23 \%$ & $1,51 \%$ \\
\hline PBZ Equity & \multirow{6}{*}{$\begin{array}{c}10 / 2005- \\
01 / 2008\end{array}$} & $78,26 \%$ & $2,18 \%$ & $4,34 \%$ & $41,88 \%$ & & & \\
\hline Crobex & & $120,45 \%$ & $3,08 \%$ & $6,80 \%$ & $40,06 \%$ & $4,73 \%$ & $0,25 \%$ & $0,40 \%$ \\
\hline Belex15 & & $112,69 \%$ & $3,26 \%$ & $9,67 \%$ & $29,96 \%$ & $9,99 \%$ & $1,03 \%$ & $1,29 \%$ \\
\hline Bux13 & & $2,30 \%$ & $0,24 \%$ & $5,62 \%$ & $-2,19 \%$ & $-0,32 \%$ & $1,87 \%$ & $2,09 \%$ \\
\hline Cetop20 & & $13,70 \%$ & $0,65 \%$ & $6,23 \%$ & $4,70 \%$ & $0,82 \%$ & $1,71 \%$ & $1,95 \%$ \\
\hline Rts50 & & $89,23 \%$ & $2,60 \%$ & $7,77 \%$ & $28,78 \%$ & $10,38 \%$ & $1,34 \%$ & $1,62 \%$ \\
\hline Raiffeisen CE & \multirow{6}{*}{$\begin{array}{c}05 / 2005- \\
01 / 2008\end{array}$} & $86,91 \%$ & $1,99 \%$ & $4,02 \%$ & $40,63 \%$ & & & \\
\hline Crobex & & $151,45 \%$ & $3,03 \%$ & $6,37 \%$ & $41,90 \%$ & $4,85 \%$ & $0,17 \%$ & $0,33 \%$ \\
\hline Atx20 & & $49,73 \%$ & $1,39 \%$ & $5,61 \%$ & $18,32 \%$ & $2,53 \%$ & $1,22 \%$ & $1,43 \%$ \\
\hline Belex15* & & $112,69 \%$ & $3,26 \%$ & $9,67 \%$ & $29,96 \%$ & $11,22 \%$ & $0,76 \%$ & $1,02 \%$ \\
\hline Bux13 & & $43,34 \%$ & $1,26 \%$ & $5,86 \%$ & $15,45 \%$ & $2,69 \%$ & $1,33 \%$ & $1,57 \%$ \\
\hline Cetop20 & & $65,10 \%$ & $1,73 \%$ & $6,33 \%$ & $21,65 \%$ & $4,08 \%$ & $1,18 \%$ & $1,41 \%$ \\
\hline$\overline{\text { Erste AE }}$ & \multirow{6}{*}{$\begin{array}{c}11 / 2005- \\
01 / 2008\end{array}$} & $76,91 \%$ & $2,23 \%$ & $\overline{4,49 \%}$ & $41,75 \%$ & $\bar{~}$ & 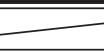 & \\
\hline Crobex & & $122,02 \%$ & $3,22 \%$ & $6,89 \%$ & $41,58 \%$ & $4,88 \%$ & $0,19 \%$ & $0,34 \%$ \\
\hline Belex15 & & $112,69 \%$ & $3,26 \%$ & $9,67 \%$ & $29,96 \%$ & $11,79 \%$ & $1,16 \%$ & $1,43 \%$ \\
\hline Cetop20 & & $26,15 \%$ & $1,04 \%$ & $5,99 \%$ & $11,40 \%$ & $2,01 \%$ & $1,64 \%$ & $1,88 \%$ \\
\hline Atx20 & & $16,47 \%$ & $0,72 \%$ & $5,59 \%$ & $6,47 \%$ & $1,00 \%$ & $1,74 \%$ & $1,97 \%$ \\
\hline Rts50 & & $102,41 \%$ & $2,93 \%$ & $7,71 \%$ & $33,40 \%$ & $19,60 \%$ & $1,53 \%$ & $1,85 \%$ \\
\hline$\overline{\text { ZB Trend }}$ & \multirow{6}{*}{$\begin{array}{c}11 / 2002- \\
01 / 2008\end{array}$} & $28,05 \%$ & $0,42 \%$ & $2,21 \%$ & $2,63 \%$ & & $=$ & \\
\hline S\&P500 & & $55,63 \%$ & $0,74 \%$ & $2,79 \%$ & $13,74 \%$ & $0,64 \%$ & $-0,17 \%$ & $-0,03 \%$ \\
\hline Crobex & & $310,24 \%$ & $2,46 \%$ & $6,40 \%$ & $32,85 \%$ & $13,72 \%$ & $-0,26 \%$ & $0,04 \%$ \\
\hline Nikkei225 & & $57,31 \%$ & $0,82 \%$ & $4,47 \%$ & $10,30 \%$ & $1,24 \%$ & $-0,11 \%$ & $0,11 \%$ \\
\hline Ftse100 & & $45,55 \%$ & $0,64 \%$ & $3,06 \%$ & $9,31 \%$ & $0,48 \%$ & $-0,11 \%$ & $0,04 \%$ \\
\hline SSE Comp & & $198,26 \%$ & $2,12 \%$ & $8,84 \%$ & $19,89 \%$ & $163,88 \%$ & $0,04 \%$ & $0,39 \%$ \\
\hline
\end{tabular}


Table 5 .

\section{PERFORMANCES OF THE LARGEST CROATIAN ACTIVELY MANAGED EQUITY MUTUAL FUNDS IN THE PERIOD FROM FEBRUARY 2008 UNTIL AUGUST 2010}

\begin{tabular}{|c|c|c|c|c|c|c|c|}
\hline \multicolumn{2}{|c|}{ Fund/Index } & $\begin{array}{l}\text { Total } \\
\text { return } \\
\end{array}$ & $\begin{array}{r}\text { Average } \mathrm{r} \\
\text { (month }\end{array}$ & $\begin{array}{l}\text { return } \\
\text { lly) }\end{array}$ & $\begin{array}{c}\text { Volatility } \\
\text { (monthly) }\end{array}$ & $\begin{array}{l}\text { Sharpe } \\
\text { Ratio } \\
\end{array}$ & \\
\hline \multicolumn{2}{|l|}{ ZZB Trend } & $-1,12 \%$ & & $0,03 \%$ & $3,84 \%$ & $-11,62 \%$ & \\
\hline \multicolumn{2}{|l|}{ PBZ Equity } & \begin{tabular}{|l|}
$-59,55 \%$ \\
\end{tabular} & & $-2,60 \%$ & $8,66 \%$ & $-35,60 \%$ & \\
\hline \multicolumn{2}{|c|}{ Raiffeisen CE } & $-67,60 \%$ & & $-3,22 \%$ & $9,57 \%$ & $-38,65 \%$ & \\
\hline \multicolumn{2}{|l|}{ ZB Aktiv } & $-51,39 \%$ & & $-2,15 \%$ & $6,79 \%$ & $-38,72 \%$ & \\
\hline \multicolumn{2}{|l|}{ Erste AE } & $-52,15 \%$ & & $-2,19 \%$ & $6,81 \%$ & $-39,30 \%$ & \\
\hline \multicolumn{2}{|l|}{ 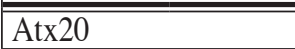 } & $-35,35 \%$ & & $-0,91 \%$ & $10,10 \%$ & $-13,80 \%$ & \\
\hline \multicolumn{2}{|l|}{ Belex15 } & $-70,81 \%$ & & $-2,99 \%$ & $14,41 \%$ & $-24,08 \%$ & \\
\hline \multicolumn{2}{|l|}{ Bux13 } & $-3,38 \%$ & & $0,37 \%$ & $9,75 \%$ & $-1,16 \%$ & \\
\hline \multicolumn{2}{|l|}{ Cetop20 } & $-19,10 \%$ & & $-0,09 \%$ & $11,03 \%$ & $-5,16 \%$ & \\
\hline \multicolumn{2}{|l|}{ Crobex } & $-58,72 \%$ & & $-2,24 \%$ & $11,67 \%$ & $-23,30 \%$ & \\
\hline \multicolumn{2}{|l|}{ Ftse100 } & $-9,49 \%$ & & $-0,16 \%$ & $5,91 \%$ & $-10,84 \%$ & \\
\hline \multicolumn{2}{|l|}{ Nikkei225 } & $-29,83 \%$ & & $-0,86 \%$ & $7,90 \%$ & $-16,91 \%$ & \\
\hline \multicolumn{2}{|l|}{ Rts50 } & $-22,50 \%$ & & $0,27 \%$ & $14,85 \%$ & $-1,39 \%$ & \\
\hline \multicolumn{2}{|l|}{ S\&P500 } & $-20,09 \%$ & & $-0,53 \%$ & $6,56 \%$ & $-15,39 \%$ & \\
\hline \multicolumn{2}{|c|}{ SSE Composite } & $-17,99 \%$ & & $0,10 \%$ & $12,21 \%$ & $-3,09 \%$ & \\
\hline ZB Aktiv & \begin{tabular}{|c|}
$\begin{array}{c}\text { Treynor } \\
\text { Ratio }\end{array}$ \\
\end{tabular} & Jensen $\alpha$ & $\begin{array}{c}\text { Jensen } \alpha \\
\text { (excl. Rf) } \\
\end{array}$ & $\begin{array}{l}\text { Raiffeise } \\
\text { CE }\end{array}$ & $\begin{array}{c}\text { Treynor } \\
\text { Ratio }\end{array}$ & Jensen $\alpha$ & $\begin{array}{l}\text { Jensen } \alpha \\
\text { (excl. Rf) }\end{array}$ \\
\hline Crobex & \begin{tabular}{|l|}
$-5,15 \%$ \\
\end{tabular} & $-1,22 \%$ & $-0,99 \%$ & Crobex & $-3,65 \%$ & $-1,66 \%$ & $-1,54 \%$ \\
\hline Rts50 & $-0,56 \%$ & $-1,39 \%$ & $-2,28 \%$ & Atx20 & $-1,82 \%$ & $-2,56 \%$ & $-2,44 \%$ \\
\hline Belex15 & $-8,11 \%$ & $-1,32 \%$ & $-1,05 \%$ & Belex15 & $-5,63 \%$ & $-1,76 \%$ & $-1,57 \%$ \\
\hline S\&P500 & $-1,31 \%$ & $-1,94 \%$ & $-1,83 \%$ & Bux13 & $-0,14 \%$ & $-3,60 \%$ & $-3,50 \%$ \\
\hline SSE Comp. & $-2,09 \%$ & $-2,74 \%$ & $-2,34 \%$ & Cetop20 & $-0,95 \%$ & $-3,34 \%$ & $-3,15 \%$ \\
\hline $\begin{array}{l}\text { PBZ } \\
\text { Equity }\end{array}$ & $\begin{array}{c}\text { Treynor } \\
\text { Ratio }\end{array}$ & Jensen $\alpha$ & $\begin{array}{l}\text { Jensen } \alpha \\
\text { (excl. Rf) } \\
\end{array}$ & Erste AE & $\begin{array}{c}\text { Treynor } \\
\text { Ratio }\end{array}$ & Jensen $\alpha$ & $\begin{array}{l}\text { Jensen } \alpha \\
\text { (excl. Rf) }\end{array}$ \\
\hline Crobex & $-3,84 \%$ & $-1,14 \%$ & $-1,00 \%$ & Crobex & $-4,98 \%$ & $-1,13 \%$ & $-0,91 \%$ \\
\hline Belex15 & $-6,27 \%$ & $-1,35 \%$ & $-1,14 \%$ & Belex15 & $-8,13 \%$ & $-1,29 \%$ & $-1,01 \%$ \\
\hline Bux13 & $-0,16 \%$ & $-3,01 \%$ & $-2,87 \%$ & Cetop20 & $-1,81 \%$ & $-2,25 \%$ & $-1,98 \%$ \\
\hline Cetop20 & $-1,49 \%$ & $-2,65 \%$ & $-2,42 \%$ & Atx20 & $-2,60 \%$ & $-1,83 \%$ & $-1,61 \%$ \\
\hline Rts50 & $-0.44 \%$ & $-2.99 \%$ & $-2,73 \%$ & Rts50 & $-0,59 \%$ & $-2.55 \%$ & $-2,24 \%$ \\
\hline ZB Trend & $\begin{array}{c}\text { Treynor } \\
\text { Ratio }\end{array}$ & Jensen $\alpha$ & $\begin{array}{l}\text { Jensen } \alpha \\
\text { (excl. Rf) } \\
\end{array}$ & & & & \\
\hline S\&P500 & $-2,01 \%$ & $-0,06 \%$ & $0,18 \%$ & & & & \\
\hline Crobex & $-12,76 \%$ & $0,00 \%$ & $0,38 \%$ & & & & \\
\hline Nikkei225 & $-3,63 \%$ & $-0,05 \%$ & $0,26 \%$ & & & & \\
\hline Ftse100 & $-1,17 \%$ & $-0,15 \%$ & $0,06 \%$ & & & & \\
\hline SSE Comp. & $-2,84 \%$ & $-0,57 \%$ & $-0,15 \%$ & & & & \\
\hline
\end{tabular}




\section{Conclusion}

Absolute and risk-adjusted returns of five largest Croatian open-end equity mutual funds were put in parallel, and each of them was compared with absolute and risk-adjusted returns of relevant benchmark stock market indices (chosen according to the geographical exposure of the funds' assets), within three different time frames, observing the effect of risk-free rate. Altogether this accounts for the total of 150 individual OLS specifications, where coefficients were taken in order to exhibit Traynor ratios and Jensen alphas.

Null hypothesis was confirmed, since Jensen alphas (both with and without the effect of the risk-free return rate) indicate underperformance of the examined funds when compared to market returns. Even though positive alphas were shown in the period of extreme (exponential) growth of the Croatian mutual fund industry $(2000$ - 2008), these alphas did not prove themselves to be sustainable in the long term (that is, for the time being), nor can they cover the management fees charged by the funds.

Certainly, there are certain drawbacks constraining the findings of this paper, and they should not be overseen. First of all, the modern history of the Croatian financial industry is not lengthy; the Republic of Croatia gained its independence in 1991, whilst the first actively managed equity mutual funds began operating at the turn of the millennium. The first passively managed equity mutual fund was established in February 2010. This does not constitute an extensive time period; nonetheless, it does not absolutely hinder the findings, as the results (although not definite and decisive) still present a vivid insight into the active management performance in Croatia ${ }^{29}$. In the future, when a larger dataset is obtainable, this kind of research should certainly be repeated.

In addition, as many researchers have noticed, the evaluation of active management performance relies heavily on the appropriateness of chosen benchmarks, therefore making the selection of these referent returns crucial. In this paper this issue was tackled by including a number of benchmarks according to the geographical risk exposure rather than selecting a single one of them.

Given all the limitations, the results still show that the active management of equity mutual funds in Croatia should make stronger commitment to their clients when deciding upon their investments, and should dedicate themselves more intensely to obtaining a certain level of return for their account.

29 Decades of data are not an imperative necessity for this kind of research; some authors have used even shorter periods - for instance, Dowen and Mann (2004) used five year time span. 


\section{BIBLIOGRAPHY}

Bogle, J. (1991). "Investing in the 1990s", Journal of Portfolio Management (17), 3: 5-14

Carhart, M. (1997). "On persistence in mutual fund performance", Journal of Finance, (52), 1: 57-82

Čondić-Jurkić, I., Dadić, T. (2008). "Investment Funds in Croatian Capital Markets, Trade Strategies and Market Tendencies", Proceedings of Zagreb Faculty of Economics and Business (6): 61-77

Daniel, K., Grinblatt, M., Titman S., Wermers, R., (1997). „Measuring Mutual Fund Performance with Characteristic-Based Benchmarks", Journal of Finance, (52), 3: 1035-1058

Dowen, R., Mann, T. (2004). "Mutual Fund Performance, Management Behavior, and Investor Costs", Financial Services Review (13), 1: 79-91

Galetić, F., Herceg, T., Morić Milovanović, B. (2007). "Microeconomic Analysis of Croatian Stock Investment Funds Market", Proceedings of Zagreb Faculty of Economics and Business (5): 431-438

Gruber, M. (1996). “Another Puzzle: The Growth in Actively Managed Mutual Funds", Journal of Finance, (51), 3: 783-810

Harlow, W., Brown, K. (2006). "The Right Answer to the Wrong Question: Identifying Superior Active Portfolio Management", Journal of Investment Management, (4), 4: 15-40

Ippolito, R. (1989). "Efficiency with Costly Information: A Study of Mutual Fund Performance", Quarterly Journal of Economics, (104), 1: 1-23

Jurić, D. (2005). "Development Perspectives of Croatian Investment Funds", Financial Theory and Practice, (29), 4: 385-398

Jensen, M. C. (1967). "The Performance of Mutual Funds in the Period 19451964", Journal of Finance, (23), 2: 389-416

Malkiel, B. (1995). "Returns from Investing in Equity Mutual Funds 1971 to 1991", Journal of Finance, (50), 2: 549-572

McLeod, W., van Vuuren, B. (2004). "Interpreting the Sharpe ratio when excess returns are negative", Investment Analysts Journal, (59): 15-20

Morić Milovanović, B., Galetić, F. (2005). "Open-end Investment Funds in Croatia", Financial Theory and Practice, (30), 1: 79-91

Novak, B., Sajter, D. (2007). "Value-At-Risk of Equity and Balanced Investment Funds in the Republic of Croatia". In: Matić, B, Novak, B., Marković, B. (ed.), Financing Development and the Restructuring of the Economy, Osijek: Faculty of Economics, pp. 1-19 
Otten, R., Bams, D. (2002). "European Mutual Fund Performance", European Financial Management, (8), 1: 75-101

Pushner, G., Rainish, R. (2001). "Performance of European focused mutual funds", American Business Review, (19), 1: 39-45

Rodríguez, J. (2008). "European Mutual Funds and Portfolio’s Country Exposure: Does Active Management Add Value?", Applied Financial Economics, (18), 8: 683-689

Sharpe, W. (1966). "Mutual Fund Performance", Journal of Business, (39), 1: 119-138

Treynor, J. (1965). "How to Rate Management of Investment Funds", Harvard Business Review, (43), 1: 63-75

Valdevit, M., Čibarić, I., Žmuk, B. (2008). "Comparative Analysis of Inequality Industry Index of Open Investment Funds in Croatia from 1999 to 2007", Proceedings of Zagreb Faculty of Economics and Business, (6): 79-98

\section{MOGU LI HRVATSKI MENADŽERI STVORITI ALFA PRINOSE? USPJEŠNOST NEKIH INVESTICIJSKIH FONDOVA U HRVATSKOJ}

\section{Sažetak}

U radu se istražuju rizikom ponderirani prinosi pet najvećih hrvatskih otvorenih dioničkih investicijskih fondova (ZB Aktiv, PBZ Equity, Raiffeisen Central Europe, Erste Adriatic Equity, i ZB Trend), te se svaki od njih pojedinačno uspoređuje s rizikom ponderiranim prinosima nekih od deset relevantnih indeksa tržišta dionica (Crobex, S\&P500, Rts50, Belex15, Atx20, Cetop20, Nikkei225, Bux13, Ftse100, and SSE Composite). Izračunani su Jensen alfa pokazatelji kako bi se dobio uvid u performanse fondova, sa ciljem procjene uspješnosti aktivno upravljanih dioničkih investicijskih fondova u Hrvatskoj.

Promatrana su tri vremenska razdoblja, i svaki je fond razmatran u zasebnom vremenskom okviru. Prvo razdoblje datira od osnutka svakog fonda do srpnja 2010., a drugo od osnutka do siječnja 2008. Poseban je interes posvećen razdoblju globalne financijske krize (u Hrvatskoj od siječnja 2008. nadalje), i prinosima fondova tijekom ove kontrakcije. Stoga, treće razdoblje promatranja datira od veljače 2008. do srpnja 2010. Sveukupno, uzeto je u obzir 150 različitih, individualnih specifikacija regresijskih modela.

Nul-hipoteza je potvrđena, jer Jensenove alfe pokazuju kako prinosi fondova ne uspijevaju nadmašiti tržišne prinose. Premda su u razdoblju ekstremnog (eksponencijalnog) rasta hrvatske industrije investicijskih fondova (u razdoblju od 2000. do 2008.) iskazani pozitivni Jensenovi pokazatelji (i to prilično maleni), isti su se pokazali neodrživima u duljem razdoblju promatranja.

Ključne riječi: Aktivno upravljanje, investicijski fondovi, Jensen alfa, Treynor, Sharpe, Hrvatska 